\title{
Long-Distance Movement of a Female Polar Bear from Canada to Russia
}

\author{
Amy C. Johnson, ${ }^{1,2}$ Jodie D. Pongracz ${ }^{3}$ and Andrew E. Derocher ${ }^{1}$
}

(Received 30 September 2016; accepted in revised form 14 December 2016)

\begin{abstract}
Polar bears (Ursus maritimus) display fidelity to large geographic regions, and their movements are influenced by sea ice distribution. Polar bear subpopulations are moderately distinct from one another, and long-distance movements between subpopulations are rare. We describe and analyze the movements of a female polar bear tracked by satellite telemetry from spring 2009 for 798 days. This female traveled an exceptionally long distance (totaling $11686 \mathrm{~km}$ ) from the sea ice off the Yukon Territory, Canada (Southern Beaufort Sea subpopulation) to Wrangel Island, Russia (Chukchi Sea subpopulation). In comparison to other polar bears in this study, this bear traveled farther, moved faster, and had a much larger home range in the first year. Furthermore, the calculation of the home range size by two different methods demonstrated that the commonly used minimum convex polygon method overestimated the home range compared to the less biased Brownian bridge movement model. This female's long-distance movement was unusual and provides additional evidence for gene flow between subpopulations. Monitoring polar bear movements is useful to track such events, which is especially important at present because sea ice loss due to climate change can affect subpopulation boundaries and influence management.
\end{abstract}

Key words: polar bear; gene flow; home range; long-distance movement; Brownian bridge movement model; minimum convex polygon; climate change; Southern Beaufort Sea; Chukchi Sea; Ursus maritimus

RÉSUMÉ. L'ours polaire (Ursus maritimus) démontre sa fidélité à de grandes régions géographiques, et ses déplacements subissent l'influence de la répartition de la glace de mer. Les sous-populations d'ours polaires sont modérément distinctes les unes des autres, et les déplacements sur de longues distances entre les sous-populations sont rares. Nous décrivons et analysons les déplacements d'une ourse polaire suivie par télémétrie satellitaire pendant 798 jours à compter du printemps 2009 . Cette femelle s'est déplacée sur une distance exceptionnellement longue (11686 km au total) depuis la glace de mer au large du territoire du Yukon, au Canada (sous-population du sud de la mer de Beaufort) jusqu'à l'île Wrangel, en Russie (sous-population de la mer des Tchouktches). Comparativement à d'autres ours polaires visés par cette étude, cette ourse s'est déplacée plus loin et plus vite, et elle avait un domaine vital beaucoup plus vaste au cours de sa première année. De plus, le calcul de la taille de son domaine vital effectué au moyen de deux méthodes différentes a permis de constater que la méthode fréquemment utilisée du polygone convexe minimum donnait lieu à la surestimation du domaine vital comparativement au modèle de mouvement moins faussé du pont brownien. Le déplacement de cette ourse sur de longues distances était inhabituel et il permet d'obtenir des preuves supplémentaires au sujet du flux génétique entre les sous-populations. La surveillance des déplacements des ours polaires est utile dans le cadre du suivi de tels événements, ce qui est particulièrement important en ce moment, car la perte de glace de mer attribuable au changement climatique peut avoir des effets sur les frontières des sous-populations et la gestion des influences.

Mots clés : ours polaire; flux génétique; domaine vital; déplacement sur de longues distances; modèle de mouvement du pont brownien; polygone convexe minimum; changement climatique; sud de la mer de Beaufort; mer des Tchouktches; Ursus maritimus

Traduit pour la revue Arctic par Nicole Giguère.

\section{INTRODUCTION}

Site fidelity, migration, and long-distance movements are all important for understanding the ecology and dynamics of a population. Movement of animals can result in gene flow and may influence population fluctuations (Slatkin, 1987; Ranta et al., 1997). Movement of individuals within the context of meta-population structure (Hanski and
Gilpin, 1997) is important for species conservation (Esler, 2000; Webster et al., 2002). For highly mobile species, understanding spatial connectivity between populations is particularly relevant.

Polar bears (Ursus maritimus) are distributed across the circumpolar Arctic in 19 subpopulations in close association with the distribution of sea ice over the continental shelf where they forage for their main prey, the

\footnotetext{
${ }^{1}$ Department of Biological Sciences, University of Alberta, Edmonton, Alberta T6G 2E9, Canada

${ }^{2}$ Corresponding author: acj1@ualberta.ca

${ }^{3}$ Wildlife Management, Environment and Natural Resources, Government of the Northwest Territories, PO Box 2749, Inuvik, Northwest Territories X0E 0T0, Canada

(C) The Arctic Institute of North America
} 
ringed seal (Pusa hispida) (Stirling and Archibald, 1977; Durner et al., 2009; Stirling and Derocher, 2012). Because of the importance of sea ice for polar bear movements and foraging success, climate change-induced sea ice loss is negatively affecting the survival, reproduction, and abundance of some subpopulations, such as the Southern Beaufort Sea subpopulation (SB) (Derocher et al., 2004; Wiig et al., 2008; Hunter et al., 2010; Regehr et al., 2010; Stirling and Derocher, 2012). Climate projections estimate that sea ice loss will continue, which may affect polar bear movements, influence distributions of the species, and threaten the persistence of subpopulations (Durner et al., 2009; Hunter et al., 2010; Molnár et al., 2010, 2014; Castro de la Guardia et al., 2013; Hamilton et al., 2014).

Long-distance movements by polar bears from their subpopulation are rarely documented, and subpopulations are considered relatively discrete (Durner and Amstrup, 1995; Amstrup et al., 2000). Polar bear movements are associated with seasonal sea ice changes because the bears rely on the ice as a platform for foraging, traveling, and mating (Ferguson et al., 1998; Durner et al., 2009; Molnár et al., 2010, 2014). In the SB shared between Canada and Alaska, some polar bears move onto land when the ice melts in the summer, whereas other bears travel north to multiyear sea ice (Amstrup et al., 2000; Stirling, 2002; Schliebe et al., 2008; Pongracz and Derocher, 2017). Pregnant female polar bears in the Beaufort Sea make maternity dens in the winter on land or sea ice (Lentfer, 1975; Fischbach et al., 2007), and females show strong site fidelity to denning regions and at-sea feeding areas (Derocher and Stirling, 1990; Ramsay and Stirling, 1990; Mauritzen et al., 2001).

As part of a multi-year study to monitor the movements of the SB, female polar bears were collared and tracked by satellite telemetry. Here, we describe the exceptionally long-distance movement of one female and compare her movements to those of other females collared as part of the same study and to the previously observed long-distance movement of another adult female from Alaska to Greenland (Durner and Amstrup, 1995). These comparisons provide insights into this rarely documented behaviour that have implications for gene flow between polar bear subpopulations.

\section{METHODS}

Polar bear location data were collected from females in the Canadian region of the southern Beaufort Sea from 2009 to 2011 (Fig. 1). Bears were immobilized with tiletamine hydrochloride and zolazepam hydrochloride (Zoletil ${ }^{\circledR}$, Laboratoires Virbac, Carros, France) using standard methods (Stirling et al., 1989). Body condition (subjective measure of body fat on a scale of 1 to 5; Stirling et al., 1989, 2008) and age (based on tooth section cementum annuli counts; Stirling et al., 1977) were recorded at capture for each bear. Adult ( $\geq 4$ years old) female bears were fitted with GPS (global positioning system) collars that had a programmable release (CR2a; Telonics, Mesa, Arizona) timed to open in 2.2 years. The GPS collars were linked to the Argos satellite system (CLS America Inc., Lanham, Maryland) and programmed to provide location data every four hours and transmit these data to a satellite once a day. GPS locations that were erroneous (i.e., not biologically possible) were omitted from analysis. Additionally, the first three days of location data after capture were omitted from movement analyses because it takes approximately three days for the movement rates of polar bears to recover from the effects of chemical immobilization during capture (Thiemann et al., 2013). All capture and handling protocols for polar bears were conducted in accordance with the guidelines of the Canadian Council on Animal Care (http:// www.ccac.ca/en_/standards/guidelines) and approved by the University of Alberta BioSciences Animal Care and Use Committee.

The movements of the female polar bear of interest (hereafter referred to as "Bear A") were analyzed and compared to the movements of four adult females from the same study that were captured in spring 2009 and had collars transmitting data in the same period as Bear A (spring 2009 to 2011). Movement analyses included the distance traveled in the first year (first 365 days postcapture) and the movement rate in the first 79 days. The distances traveled were compared for the first year to ensure that movements were compared for the same length of time, while the movement rates were calculated for the first 79 days to allow for comparison with Durner and Amstrup (1995). Movement metrics were calculated using ArcGIS (ArcGIS version 10.3.1, Environmental Systems Research Institute, Redlands, California). Additionally, the swim speed for a long-distance swimming event by Bear A was calculated as $0.75 \mathrm{~km} / \mathrm{h}$. We then used a correction factor of $1.4 \times$ to account for locations that the collar failed to transmit while Bear A was swimming (Pilfold et al., 2017), which resulted in an adjusted swim speed of $1.05 \mathrm{~km} / \mathrm{h}$.

In addition, the annual home range in the first year was calculated for each bear using two methods. First, we created minimum convex polygons (MCPs) using ArcGIS to estimate the home range, which allowed comparison with previous home range estimates for polar bears (e.g., Parks et al., 2006; McCall et al., 2015). For Bear A, an annual MCP home range for her second year of tracking (last 365 days of tracking) was also calculated to compare her initial movements with her later movements. MCPs are a common method, but they can produce biased home range estimates, e.g., by overestimating home range size (Burgman and Fox, 2003). Therefore, Brownian bridge movement models (BBMMs) were also used to estimate the home ranges. This method is based on the movement path and models an animal's utilization distribution, therefore incorporating the intensity of use of different areas by the animal (Horne et al., 2007; Kranstauber et al., 2012). BBMMs were calculated in $\mathrm{R}$ ( $\mathrm{R}$ Core Team, 2015) using the adehabitatHR package (Calenge, 2006), and the variance of the Brownian motion $\left(\sigma_{m}^{2}\right)$ was estimated using the maximum likelihood 


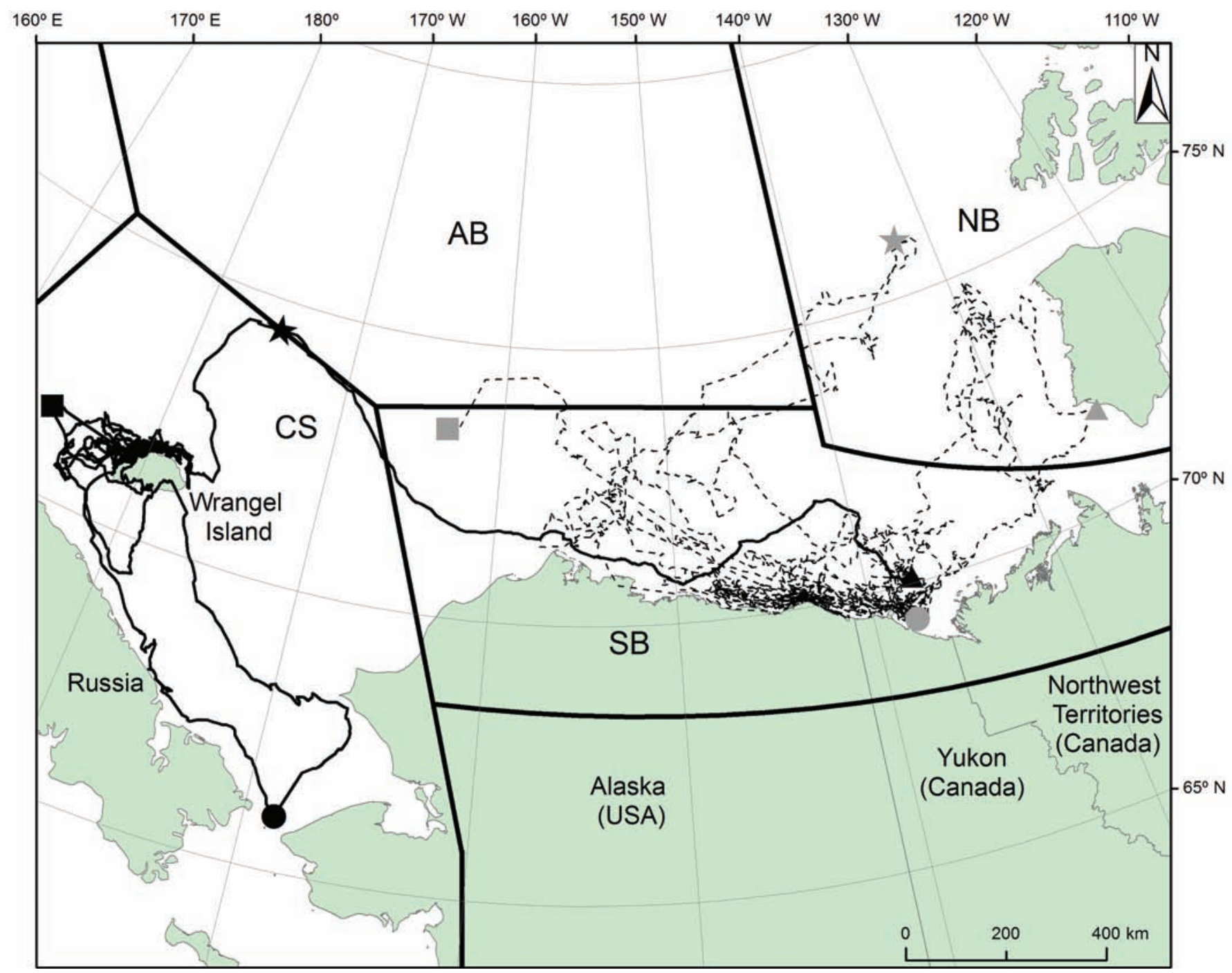

FIG. 1. Map showing the long-distance movement of Bear A (solid black line) and those of a subset of four other adult female polar bears (dashed black lines) in 2009-11. The symbols indicate the farthest extent of travel in each direction (star $=\mathrm{N}$, triangle $=\mathrm{E}$, square $=\mathrm{W}$, and circle $=\mathrm{S})$ for Bear A $($ black) and the subset of four bears (grey). The thicker black lines indicate approximate boundaries of four polar bear subpopulations-Southern Beaufort Sea (SB), Northern Beaufort Sea (NB), Chukchi Sea (CS), and Arctic Basin (AB) — as identified by the Polar Bear Specialist Group of the Species Survival Commission, International Union for Conservation of Nature (Obbard et al., 2010).

technique (Horne et al., 2007) with a telemetry error $\left(\delta^{2}\right)$ of $30 \mathrm{~m}$, which is a reasonable estimate for GPS collar data (Tomkiewicz et al., 2010; Kranstauber et al., 2012).

\section{RESULTS}

Polar bear research has been conducted in the southern Beaufort Sea for the past 40 years, but Bear A had not previously been handled by scientists. Bear A was a fouryear-old nulliparous female who was captured on 20 April 2009 in average body condition. The GPS collar on Bear A transmitted data for 798 days, from 24 April 2009 to 30 June 2011, before the collar released as programmed. Bear A traveled west from Yukon, Canada, across northern Alaska to Wrangel Island in Russia, then moved south along the coast of Russia before crossing to the west coast of Alaska and returning north to Wrangel Island (total distance traveled $=11686 \mathrm{~km}$; Fig. 1). The four other female bears included for comparison (ages 5, 7, 13, and 15 years at capture) were also captured in spring 2009 in average body condition and had combined location data from 24 April 2009 to 13 November 2011. Two of these bears were captured for the first time, and the other two had been handled previously. These four bears had localized travel in the Beaufort Sea region and mainly remained near the coast of Alaska and Canada, with some northward movement before returning to the coast (Fig. 1). Compared to the mean movements of the four other females, Bear A traveled 1.3 times as far in the first year and moved 1.4 times as fast in the first 79 days (Table 1).

When calculated using the MCP method, Bear A's firstyear home range area was 5.4 times the size of the mean home range of the other four females, while her second-year home range area was only 0.11 the size of the others' mean home range (Table 1). When calculated using the BBMM 
TABLE 1. Movement metrics for Bear A and a subset of four adult females from the Southern Beaufort Sea subpopulation. The longdistance movement of another adult female previously described by Durner and Amstrup (1995) is included for comparison. SE = standard error.

\begin{tabular}{|c|c|c|c|}
\hline & $\begin{array}{c}\text { Bear A } \\
(2009-11)\end{array}$ & $\begin{array}{l}\text { Subset of four bears } \\
\qquad(2009-11)\end{array}$ & $\begin{array}{l}\text { Previously described female } \\
\qquad(1992-93)\end{array}$ \\
\hline Distance traveled in first year $(\mathrm{km})$ & 7546 & $\begin{array}{c}\text { Mean }=6035, \\
\mathrm{SE}=569.4, \\
\text { Range }=4677 \text { to } 7444\end{array}$ & 5256 \\
\hline Rate of travel in first 79 days $(\mathrm{km} / \mathrm{hour})$ & $\begin{array}{c}\text { Mean }=1.46, \\
\mathrm{SE}=0.06, \\
\text { Range }=0 \text { to } 5.40\end{array}$ & $\begin{array}{c}\mathrm{Mean}=1.02 \\
\mathrm{SE}=0.02 \\
\text { Range }=0 \text { to } 6.02\end{array}$ & $\begin{array}{c}\text { Mean }=1.4, \\
\text { Range }=0.2 \text { to } 3.7\end{array}$ \\
\hline Minimum convex polygon first-year home range size $\left(\mathrm{km}^{2}\right)$ & $952813^{1}$ & $\begin{array}{c}\text { Mean }=175622, \\
\mathrm{SE}=28096, \\
\text { Range }=115967 \text { to } 251426\end{array}$ & $\begin{array}{c}1902108 \\
\text { (U.S. Geological Survey, } \\
\text { unpubl. data) }\end{array}$ \\
\hline Brownian Bridge movement model first-year home range size $\left(\mathrm{km}^{2}\right)$ & 40282 & $\begin{array}{c}\text { Mean }=22164 \\
\mathrm{SE}=3598 \\
\text { Range }=15563 \text { to } 28643\end{array}$ & N/A \\
\hline Total duration of collar deployment (days) & 798 & $\begin{array}{c}\text { Mean }=543 \\
\mathrm{SE}=127.4 \\
\text { Range }=391 \text { to } 924\end{array}$ & 576 \\
\hline Number of locations in first year & 1867 & $\begin{array}{c}\text { Mean }=1617, \\
\mathrm{SE}=152.8, \\
\text { Range }=1161 \text { to } 1799\end{array}$ & $\begin{array}{c}115 \\
\text { (U.S. Geological Survey, } \\
\text { unpubl. data) }\end{array}$ \\
\hline
\end{tabular}

${ }^{1}$ In the second year, Bear A’s home range size was $20486 \mathrm{~km}^{2}$.

method, Bear A's first-year home range was 1.8 times as large as that of the other females. Comparing the results from the two home range methods, Bear A's first-year MCP home range was 23.7 times as large as her first-year BBMM home range (Table 1, Fig. 2).

\section{DISCUSSION}

Long-distance movement by polar bears is rarely documented (Durner and Amstrup, 1995), and most bears in the Beaufort Sea move between different habitats within a year and show fidelity to large geographic regions (Amstrup et al., 2000; Stirling, 2002). Bear A in this study was unusual because her movements took her from the SB in Canada to the Chukchi Sea subpopulation (CS) in Russia over the first two months of collar deployment. Ice drift is variable across seasons and locations, making it difficult to determine whether this bear was moving with or against the sea ice circulation as she moved from the SB to the CS. Bear A traveled both farther and faster than the other adult female bears in this study and also had the most western and southern locations of the bears examined (Fig. 1). The female polar bear documented by Durner and Amstrup (1995) had a larger annual home range and traveled at about the same speed but covered a shorter overall distance than Bear A. However, the distance reported by Durner and Amstrup (1995) was underestimated because collars in use at that time recorded location data less frequently than current GPS collars (Table 1; Andersen et al., 2008). These bears were similar in that they both displayed more extensive travel than bears from other subpopulations (e.g., Ferguson et al., 1999; McCall et al., 2015). Both individuals showed directed long-distance travel away from the subpopulations where they were captured: the bear monitored by Durner and Amstrup (1995) eventually resided off the northern Greenland coast, and Bear A in our study traveled out of the SB and into the CS.

Even though polar bear home ranges are variable and differ between individuals and subpopulations (Ferguson et al., 1999; McCall et al., 2015), Bear A's first-year MCP home range of $952813 \mathrm{~km}^{2}$ was considerably larger than those of the other females in this study. Her first-year MCP home range was also larger than the mean and maximum for adult females in the SB from 1985 to 1995 (mean = $166694 \mathrm{~km}^{2}$; maximum $=616800 \mathrm{~km}^{2}$ ) recorded by Amstrup et al. (2000). Similarly, her MCP home range in the first year was larger than the mean and maximum for adult females from subpopulations in Arctic Canada and Greenland $\left(\right.$ mean $=125500 \mathrm{~km}^{2} ;$ maximum $\left.=540700 \mathrm{~km}^{2}\right)$ from 1989 to 1997 (Ferguson et al., 1999). Furthermore, Bear A's first-year MCP home range was also larger than the mean and maximum for adult females in the Western Hudson Bay subpopulation from 1992 to 1998 (mean = $106613 \mathrm{~km}^{2}$; maximum $\left.=311646 \mathrm{~km}^{2}\right)($ Parks et al., 2006) and from 2004 to 2012 (mean $=353557 \mathrm{~km}^{2}$; maximum $<500000 \mathrm{~km}^{2}$ ) $($ McCall et al., 2015). Her large home range in the first year resulted from her initial movement from Yukon to Wrangel Island in the first two months and her subsequent travel along the coasts of Russia and Alaska before returning to Wrangel Island. The conclusions of our study (i.e., that Bear A had a larger first-year home range than the other four females) remained the same when the home ranges were calculated using the BBMM method; however, the MCP method overestimated the home range sizes, while the BBMM method produced less biased 


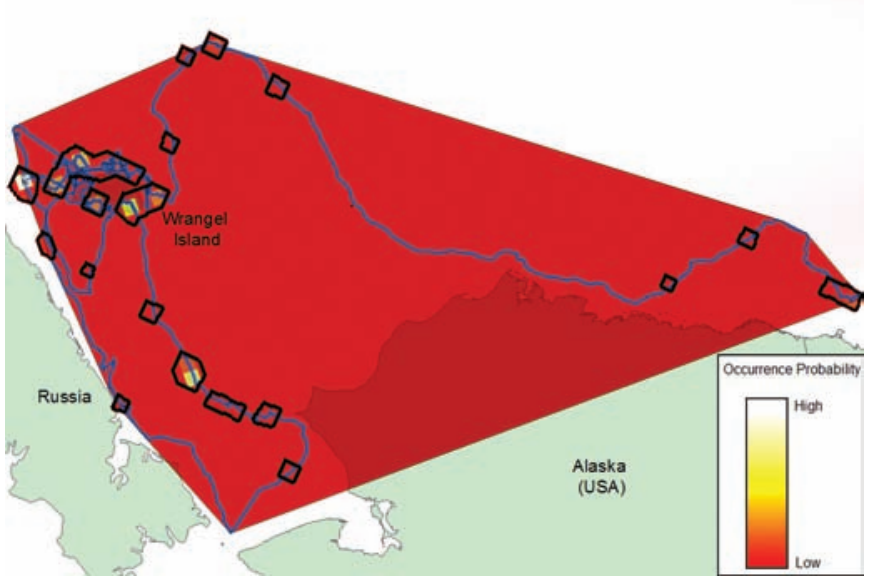

FIG. 2. A comparison of the first-year home range estimates for Bear A calculated by two methods: Minimum convex polygon (MCP) and Brownian Bridge movement model (BBMM). The MCP home range, shown as the large red polygon, overestimates the home range size. The BBMM home range is shown as the smaller polygons outlined in black along Bear A's movement track (thin blue line). Within these polygons, white and yellow indicate the highest probability of occurrence. The BBMM method produces a less biased estimate because it incorporates the animal's movement path, the order of GPS locations, and the time between them.

estimates (Table 1, Fig. 2). BBMMs take into account both the order of GPS locations and the time between them while modeling the animal's movement path (Horne et al., 2007; Kranstauber et al., 2012), and this method therefore has advantages over traditional MCP home range estimates.

After the long-distance movements in her first year, Bear A traveled locally close to Wrangel Island, and her second-year MCP home range was smaller than that of the other females in this study and those of most other females in previous studies. Wrangel Island is the major polar bear maternity denning location in the Chukchi Sea and is a common summering area for all polar bears (Belikov, 1980; Uspenski and Belikov, 1980; Garner et al., 1994). The fact that Bear A spent 26 days (28 December 2009 to 23 January 2010) in approximately the same location on Wrangel Island suggests that she made a temporary den, which some bears use for shelter under unfavourable conditions such as poor food or bad weather (Schweinsburg, 1979; Ramsay and Stirling, 1990; Ferguson et al., 2001). This temporary den use appeared to follow a long-distance swimming event (54 km over three days) with an adjusted swim speed of $1.05 \mathrm{~km} / \mathrm{h}$, which is within the adjusted swim speed range ( 0.5 to $3.7 \mathrm{~km} / \mathrm{h}$ ) noted by Pilfold et al. (2017). Such longdistance swims, which can be energetically expensive, are increasing in frequency in the Beaufort Sea as a result of changing sea ice conditions (Pilfold et al., 2017). The following year, Bear A spent 125 days (8 December 2010 to 11 April 2011) in approximately the same location on Wrangel Island, which contributed to her smaller home range in the second year. Polar bears overwinter in maternity dens and emerge from dens on Wrangel Island from February to April (Uspenski and Kistchinski, 1972). Given the nulliparous state of Bear A at capture, it is likely that this was her first maternity den. After den emergence,
Bear A traveled close to shore, which is common for females with small cubs because cubs are at risk of infanticide or hypothermia (Derocher and Stirling, 1990; Durner and Amstrup, 1995; Pilfold et al., 2014).

The original subpopulation of Bear A is unknown, as it was for the female polar bear described by Durner and Amstrup (1995). It is possible that Bear A was from the SB and traveled to the CS, or that she made a long-distance movement from the CS to the SB (where she was captured) before returning to the CS. Either way, the long-distance movement of this bear supports the potential for gene flow between these two subpopulations. Bear A's movements are noteworthy because long-distance movements among polar bear subpopulations are rarely documented (Durner and Amstrup, 1995), as is demonstrated in this study, which tracked 65 bears as part of the multi-year monitoring program in the SB from 2007 to 2012 and found only one bear that moved such a long distance. Female polar bears often return to the region where their mother denned and display fidelity to these denning areas (Derocher and Stirling, 1990; Zeyl et al., 2010); therefore, they may not be major contributors to gene flow. However, genetic analyses of the SB and CS indicate a region of overlap, small genetic differences, and both females and males contributing to gene flow between subpopulations (Paetkau et al., 1999; Cronin et al., 2006), and Bear A's movements support these findings. Analyses of telemetry data in this region indicate subpopulation overlap, but movements far into adjacent subpopulations are uncommon (Amstrup et al., 2004).

While the long-distance movement by Bear A occurred in a period of changing environmental conditions, Durner and Amstrup (1995) found that their bear traveled from Alaska to Greenland in a period when sea ice melt was not extensive. It is therefore possible that long-distance movements by polar bears may be influenced by a variety of factors, such as exploration, dispersal, or habitat conditions, but the reasons for this behaviour are not well understood. The SB has experienced major changes in sea ice habitat (Parkinson, 2014), which have resulted in associated declines in survival and reproduction (Hunter et al., 2010; Regehr et al., 2010). Climate change is therefore already affecting the dynamics of the subpopulation, while future changes to subpopulation boundaries may influence conservation and management. Long-distance movements by polar bears may become more common as climate change causes sea ice to decline (Derocher et al., 2004; McKeon et al., 2016). It is important to understand this possibility, because these longdistance movements could increase gene flow and therefore alter subpopulation boundaries.

\section{ACKNOWLEDGEMENTS}

We would like to acknowledge support from ArcticNet, the Canadian Association of Zoos and Aquariums, the Canadian Wildlife Federation, Environment Canada, Hauser Bears, the Natural Sciences and Engineering Research Council of 
Canada, Polar Bears International, the Polar Continental Shelf Program, Quark Expeditions Ltd., the Bureau of Ocean Energy Management, United States Department of the Interior, and the World Wildlife Fund (Canada and International). We furthermore thank Marie Auger-Méthé, Oliver Barker, Seth Cherry, Stephen Hamilton, Alysa McCall, Péter Molnár, Nick Pilfold, Vicki Sahanatien, and Mike Woodcock for assistance in the field. We also thank David Yurkowski and two anonymous reviewers for their comments.

\section{REFERENCES}

Amstrup, S.C., Durner, G.M., Stirling, I., Lunn, N.J., and Messier, F. 2000. Movements and distribution of polar bears in the Beaufort Sea. Canadian Journal of Zoology 78(6):948-966. https://doi.org/10.1139/z00-016

Amstrup, S.C., McDonald, T.L., and Durner, G.M. 2004. Using satellite radiotelemetry data to delineate and manage wildlife populations. Wildlife Society Bulletin 32(3):661-679.

Andersen, M., Derocher, A.E., Wiig, Ø., and Aars, J. 2008. Movements of two Svalbard polar bears recorded using geographical positioning system satellite transmitters. Polar Biology 31(8):905-911. https://doi.org/10.1007/s00300-008-0428-x

Belikov, S.E. 1980. Distribution and structure of dens of female polar bears in Wrangel Island. Bears: Their Biology and Management 4:117.

https://doi.org/10.2307/3872852

Burgman, M.A., and Fox, J.C. 2003. Bias in species range estimates from minimum convex polygons: Implications for conservation and options for improved planning. Animal Conservation 6(1):19-28. https://doi.org/10.1017/s1367943003003044

Calenge, C. 2006. The package "adehabitat" for the R software: A tool for the analysis of space and habitat use by animals. Ecological Modelling 197(3-4):516-519. https://doi.org/10.1016/j.ecolmodel.2006.03.017

Castro de la Guardia, L., Derocher, A.E., Myers, P.G., Terwisscha van Scheltinga, A.D., and Lunn, N.J. 2013. Future sea ice conditions in western Hudson Bay and consequences for polar bears in the 21st century. Global Change Biology 19(9):26752687.

https://doi.org/10.1111/gcb.12272

Cronin, M.A., Amstrup, S.C., and Scribner, K.T. 2006. Microsatellite DNA and mitochondrial DNA variation in polar bears (Ursus maritimus) from the Beaufort and Chukchi Seas, Alaska. Canadian Journal of Zoology 84(5):655-660. https://doi.org/10.1139/Z06-039

Derocher, A.E., and Stirling, I. 1990. Distribution of polar bears (Ursus maritimus) during the ice-free period in western Hudson Bay. Canadian Journal of Zoology 68(7):1395-1403. https://doi.org/10.1139/z90-208

Derocher, A.E., Lunn, N.J., and Stirling, I. 2004. Polar bears in a warming climate. Integrative \& Comparative Biology 44(2):163-176.

https://doi.org/10.1093/icb/44.2.163
Durner, G.M., and Amstrup, S.C. 1995. Movements of a polar bear from northern Alaska to northern Greenland. Arctic 48(4):338-341.

https://doi.org/10.14430/arctic1257

Durner, G.M., Douglas, D.C., Nielson, R.M., Amstrup, S.C., McDonald, T.L., Stirling, I., Mauritzen, M., et al. 2009. Predicting 21st-century polar bear habitat distribution from global climate models. Ecological Monographs 79(1):25-58. https://doi.org/10.1890/07-2089.1

Esler, D. 2000. Applying metapopulation theory to conservation of migratory birds. Conservation Biology 14(2):366-372. https://doi.org/10.1046/j.1523-1739.2000.98147.x

Ferguson, S.H., Taylor, M.K., Born, E.W., and Messier, F. 1998. Fractals, sea-ice landscape and spatial patterns of polar bears. Journal of Biogeography 25(6):1081-1092.

Ferguson, S.H., Taylor, M.K., Born, E.W., Rosing-Asvid, A., and Messier, F. 1999. Determinants of home range size for polar bears (Ursus maritimus). Ecology Letters 2(5):311-318. https://doi.org/10.1046/j.1461-0248.1999.00090.x

__— 2001. Activity and movement patterns of polar bears inhabiting consolidated versus active pack ice. Arctic 54(1):4954.

https://doi.org/10.14430/arctic763

Fischbach, A.S., Amstrup, S.C., and Douglas, D.C. 2007. Landward and eastward shift of Alaskan polar bear denning associated with recent sea ice changes. Polar Biology 30(11):1395-1405. https://doi.org/10.1007/s00300-007-0300-4

Garner, G.W., Belikov, S.E., Stishov, M.S., Barnes, V.G.J., and Arthur, S.M. 1994. Dispersal patterns of maternal polar bears from the denning concentration on Wrangel Island. Bears: Their Biology and Management 9:401-410. https://doi.org/10.2307/3872726

Hamilton, S.G., Castro de la Guardia, L., Derocher, A.E., Sahanatien, V., Tremblay, B., and Huard, D. 2014. Projected polar bear sea ice habitat in the Canadian Arctic Archipelago. PLOS ONE 9: e113746. https://doi.org/10.1371/journal.pone.0113746

Hanski, I.A., and Gilpin, M.E., eds. 1997. Metapopulation biology: Ecology, genetics, and evolution. San Diego: Academic Press.

Horne, J.S., Garton, E.O., Krone, S.M., and Lewis, J.S. 2007. Analyzing animal movements using Brownian bridges. Ecology 88(9):2354-2363. https://doi.org/10.1890/06-0957.1

Hunter, C.M., Caswell, H., Runge, M.C., Regehr, E.V, Amstrup, S.C., and Stirling, I. 2010. Climate change threatens polar bear populations: A stochastic demographic analysis. Ecology 91(10):2883-2897. https://doi.org/10.1890/09-1641.1

Kranstauber, B., Kays, R., LaPoint, S.D., Wikelski, M., and Safi, K. 2012. A dynamic Brownian bridge movement model to estimate utilization distributions for heterogeneous animal movement. Journal of Animal Ecology 81(4):738-746. https://doi.org/10.1111/j.1365-2656.2012.01955.x

Lentfer, J.W. 1975. Polar bear denning on drifting sea ice. Journal of Mammalogy 56(3):716-718.

https://doi.org/10.2307/1379497 
Mauritzen, M., Derocher, A.E., and Wiig, Ø. 2001. Space-use strategies of female polar bears in a dynamic sea ice habitat. Canadian Journal of Zoology 79(9):1704-1713.

https://doi.org/10.1139/z01-126

McCall, A.G., Derocher, A.E., and Lunn, N.J. 2015. Home range distribution of polar bears in western Hudson Bay. Polar Biology 38(3):343-355. https://doi.org/10.1007/s00300-014-1590-y

McKeon, C.S., Weber, M.X., Alter, S.E., Seavy, N.E., Crandall, E.D., Barshis, D.J., Fechter-Leggett, E.D., and Oleson, K.L.L. 2016. Melting barriers to faunal exchange across ocean basins. Global Change Biology 22(2):465-473. https://doi.org/10.1111/gcb.13116

Molnár, P.K., Derocher, A.E., Thiemann, G.W., and Lewis, M.A. 2010. Predicting survival, reproduction and abundance of polar bears under climate change. Biological Conservation 143(7):1612-1622. https://doi.org/10.1016/j.biocon.2010.04.004

___ 2014. Corrigendum to "Predicting survival, reproduction and abundance of polar bears under climate change" [Biol. Conserv. 143 (2010) 1612-1622]. Biological Conservation 177:230-231.

https://doi.org/10.1016/j.biocon.2014.07.001

Obbard, M.E., Thiemann, G.W., Peacock, E., and DeBruyn, T.D., comp. and eds. 2010. Polar bears: Proceedings of the 15th Working Meeting of the IUCN/SSC Polar Bear Specialist Group, Copenhagen, Denmark, 29 June-3 July 2009. Occasional Paper of the IUCN Species Survival Commission No. 43. Gland, Switzerland: International Union for Conservation of Nature.

Paetkau, D., Amstrup, S.C., Born, E.W., Calvert, W., Derocher, A.E., Garner, G.W., Messier, F., et al. 1999. Genetic structure of the world's polar bear populations. Molecular Ecology 8(10):1571-1584. https://doi.org/10.1046/j.1365-294x.1999.00733.x

Parkinson, C.L. 2014. Spatially mapped reductions in the length of the Arctic sea ice season. Geophysical Research Letters 41(12):4316-4322. https://doi.org/10.1002/2014GL060434

Parks, E.K., Derocher, A.E., and Lunn, N.J. 2006. Seasonal and annual movement patterns of polar bears on the sea ice of Hudson Bay. Canadian Journal of Zoology 84(9):1281-1294. https://doi.org/10.1139/Z06-115

Pilfold, N.W., Derocher, A.E., and Richardson, E. 2014. Influence of intraspecific competition on the distribution of a wideranging, non-territorial carnivore. Global Ecology and Biogeography 23(4):425-435.

https://doi.org/10.1111/geb.12112

Pilfold, N.W., McCall, A., Derocher, A.E., Lunn, N.J., and Richardson, E. 2017. Migratory response of polar bears to sea ice loss: To swim or not to swim. Ecography 40(1):189-199. https://doi.org/10.1111/ecog.02109

Pongracz, J.D., and Derocher, A.E. 2017. Summer refugia of polar bears (Ursus maritimus) in the southern Beaufort Sea. Polar Biology 40(4):753-763.

https://doi.org/10.1007/s00300-016-1997-8
R Core Team. 2015. R: A language and environment for statistical computing. Vienna, Austria: R Foundation for Statistical Computing. https://www.R-project.org/

Ramsay, M.A., and Stirling, I. 1990. Fidelity of female polar bears to winter-den sites. Journal of Mammalogy 71(2):233-236. https://doi.org/10.2307/1382172

Ranta, E., Kaitala, V., and Lundberg, P. 1997. The spatial dimension in population fluctuations. Science 278(5343):1621-1623. https://doi.org/10.1126/science.278.5343.1621

Regehr, E.V., Hunter, C.M., Caswell, H., Amstrup, S.C., and Stirling, I. 2010. Survival and breeding of polar bears in the southern Beaufort Sea in relation to sea ice. Journal of Animal Ecology 79(1):117-127. https://doi.org/10.1111/j.1365-2656.2009.01603.x

Schliebe, S., Rode, K.D., Gleason, J.S., Wilder, J., Proffitt, K., Evans, T.J., and Miller, S. 2008. Effects of sea ice extent and food availability on spatial and temporal distribution of polar bears during the fall open-water period in the southern Beaufort Sea. Polar Biology 31(8):999-1010. https://doi.org/10.1007/s00300-008-0439-7

Schweinsburg, R.E. 1979. Summer snow dens used by polar bears in the Canadian High Arctic. Arctic 32(2):165-169. https://doi.org/10.14430/arctic2616

Slatkin, M. 1987. Gene flow and the geographic structure of natural populations. Science 236(4803):787-792. https://doi.org/10.1126/science. 3576198

Stirling, I. 2002. Polar bears and seals in the eastern Beaufort Sea and Amundsen Gulf: A synthesis of population trends and ecological relationships over three decades. Arctic 55(5):5976. https://doi.org/10.14430/arctic735

Stirling, I., and Archibald, W.R. 1977. Aspects of predation of seals by polar bears. Journal of the Fisheries Research Board of Canada 34(8):1126-1129.

https://doi.org/10.1139/f77-169

Stirling, I., and Derocher, A.E. 2012. Effects of climate warming on polar bears: A review of the evidence. Global Change Biology 18(9):2694-2706.

https://doi.org/10.1111/j.1365-2486.2012.02753.x

Stirling, I., Jonkel, C., Smith, P., Robertson, R., and Cross, D. 1977. The ecology of the polar bear (Ursus maritimus) along the western coast of Hudson Bay. Occasional Paper of the Canadian Wildlife Service 33. Ottawa: Minister of Supply and Services. 64 p.

Stirling, I., Spencer, C., and Andriashek, D. 1989. Immobilization of polar bears (Ursus maritimus) with Telazol ${ }^{\circledR}$ in the Canadian Arctic. Journal of Wildlife Diseases 25(2):159-168. https://doi.org/10.7589/0090-3558-25.2.159

Stirling, I., Thiemann, G.W., and Richardson, E. 2008. Quantitative support for a subjective fatness index for immobilized polar bears. Journal of Wildlife Management 72(2):568-574. https://doi.org/10.2193/2007-123

Thiemann, G.W., Derocher, A.E., Cherry, S.G., Lunn, N.J., Peacock, E., and Sahanatien, V. 2013. Effects of chemical immobilization on the movement rates of free-ranging polar bears. Journal of Mammalogy 94(2):386-397. https://doi.org/10.1644/12-MAMM-A-230.1 
Tomkiewicz, S.M., Fuller, M.R., Kie, J.G., and Bates, K.K. 2010. Global positioning system and associated technologies in animal behaviour and ecological research. Philosophical Transactions of the Royal Society B: Biological Sciences 365(1550):2163-2176. https://doi.org/10.1098/rstb.2010.0090

Uspenski, S.M., and Belikov, S.E. 1980. Data on the winter ecology of the polar bear in Wrangel Island. Bears: Their Biology and Management 4:119. https://doi.org/10.2307/3872853

Uspenski, S.M., and Kistchinski, A.A. 1972. New data on the winter ecology of the polar bear (Ursus maritimus Phipps) on Wrangel Island. A Selection of Papers from the Second International Conference on Bear Research and Management, 6-9 November 1970, Calgary, Alberta. IUCN Publications New Series 23:181-197.

https://doi.org/10.2307/3872582
Webster, M.S., Marra, P.P., Haig, S.M., Bensch, S., and Holmes, R.T. 2002. Links between worlds: Unraveling migratory connectivity. Trends in Ecology \& Evolution 17(2):76-83. https://doi.org/10.1016/S0169-5347(01)02380-1

Wiig, Ø., Aars, J., and Born, E.W. 2008. Effects of climate change on polar bears. Science Progress 91(2):151-173. https://doi.org/10.3184/003685008x324506

Zeyl, E., Ehrich, D., Aars, J., Bachmann, L., and Wiig, Ø. 2010. Denning-area fidelity and mitochondrial DNA diversity of female polar bears (Ursus maritimus) in the Barents Sea. Canadian Journal of Zoology 88(12):1139-1148.

https://doi.org/10.1139/Z10-078 